Materiales de Construcción

Vol. 65, Issue 318, April-June 2015, e051

ISSN-L: 0465-2746

http://dx.doi.org/10.3989/mc.2015.01614

\title{
Use of bottom ash from thermal power plant and lime as filler in bituminous mixtures
}

\author{
E. López-López $\bowtie$, Á. Vega-Zamanillo, M.Á. Calzada-Pérez, M.A. Taborga-Sedano \\ University of Cantabria (Santander, Spain) \\ \estebanlopeziccp@gmail.com
}

Received 3 March 2014

Accepted 12 August 2014

Available on line 24 March 2015

\begin{abstract}
This study focuses on the characterization of bottom ash (PCC-BA) and determining the mechanical characteristics of hot mix asphalt (HMA) using PCC-BA and hydrated lime (HL) as filler. Physical and chemical characterization of the bottom ash was carried out to evaluate its eventual reutilization as filler substitute. The materials tested in this study were made using $0 \%, 25 \%, 50 \%, 70 \%$ and $100 \%$ of PCC-BA combined with HL. HMA mixes were evaluated in terms of their engineering properties, namely: air voids in the mixes, water sensitivity, stiffness modulus, performance in wheel tracking test and fatigue resistance.

The results obtained indicate that HMA mixes with a filler blend of $70 \%$ PCC-BA and 30\% HL fulfil
\end{abstract} European standards and are suitable for light traffic or small infrastructures.

KEYWORDS: Waste treatment; Lime; Filler; Mixture proportion; Mechanical properties

Citation/Citar como: López-López, E.; Vega-Zamanillo, A.; Calzada-Pérez, M.A.; Taborga-Sedano, M.A. (2015) Use of bottom ash from thermal power plant and lime as filler in bituminous mixtures. Mater. Construcc. 65 [318], e051 http://dx.doi.org/10.3989/mc.2015.01614.

RESUMEN: Empleo de cenizas de fondo de central térmica y cal como filler en mezclas bituminosas. Este estudio se centra en la caracterización de las cenizas de fondo (PCC-BA) y la determinación de las características mecánicas de mezclas bituminosas en caliente (HMA), utilizando cenizas de fondo y la cal hidratada (HL) como filler. Se realizó la caracterización física y química de las cenizas de fondo para evaluar su empleo como sustituto de filler. Las mezclas ensayadas en este estudio se realizaron utilizando $0 \%, 25 \%, 50 \%, 70 \%$ y $100 \%$ de cenizas de fondo combinadas con cal hidratada. Se evaluaron propiedades ingenieriles de las mezclas bituminosas, tales como los huecos de aire en las mezclas, la sensibilidad al agua, el módulo de rigidez, el ensayo de pista y la resistencia a la fatiga.

Los resultados obtenidos indican que las mezclas bituminosas fabricadas con una combinación de filler del $70 \%$ de cenizas de fondo y el $30 \%$ cal hidratada, cumplen con las normas europeas y son adecuados para su aplicación con tráficos ligeros o en pequeñas infraestructuras.

PALABRAS CLAVE: Tratamiento de residuos; Cal; Filler; Dosificación de mezclas; Propiedades mecánicas

Copyright: (C) 2015 CSIC. This is an open-access article distributed under the terms of the Creative Commons Attribution-Non Commercial (by-nc) Spain 3.0 License.

\section{INTRODUCTION}

According to the International Energy Agency (IEA), energy production based on coal combustion in thermal power plants over the last years accounted for roughly $25 \%$ of the total world production and a $28.80 \%$ share is expected for the year 2030. Pulverised coal combustion (PCC) in power plant furnaces creates, among others, a series of inert character residues called ashes (1). 
There are two kinds of ashes, fly ash and bottom ash. Fly ashes account for roughly $80 \%$ of the ashes produced and generally have high levels of lime and silicates, which give them great binder power. Bottom ashes, which make up the remaining $20 \%$, are a black granular material of inorganic nature and high porosity, which have lower contents in these compounds and so are hardly used for concrete manufacturing, the dump being their traditional destination $(56.18 \%$ in the USA in 2008 according to data from the ACAA) (2).

In the current context, this situation is incompatible with the legislation promoted by the European Union for environmental conservation. The exploitation of these bottom ashes for flexible road surface construction can reduce the cost of dumping and diminish the use of non-renewable natural materials. In fact, studies on this same ash have already been carried out in order to evaluate its use for road embankment construction (3).

This study focuses on the characterization of bottom ash and assesses the performance and properties of three bituminous mixtures using this material as filler, mixed with lime, in order to determine its suitability as a layer in road surfaces.

\section{MATERIALS}

The materials used in this study were bottom ash from the thermal power plant in Soto de Ribera, Asturias (Spain), crushed aggregate, B-50/70 bituminous binder and hydrated lime.

\subsection{Bottom ash}

The ash used is produced by combustion of pulverised coal in the power plant furnace and comes from the precipitation in the pipelines that carry away the coal combustion fumes. As the granulometric table below shows (Table 1), the ash has a maximum particle size intermediate between the slag collected in the boiler ash pit and the fly ash.

The chemical characterisation process of the ash is very similar to the one carried out by Forteza, R. et al. in 2004 (4) to characterise the bottom ash from the incineration of urban solid waste (Municipal solid waste incineration bottom ash, (MSWI-BA)). The identification and quantification of the content of the crystalline and amorphous phases of the bottom ash from Soto de Ribera was carried out by X-ray diffraction (X-ray diffractometer analysis (XRD)) (Figure 1). In this case, it can be seen that the

TABLE 1. Granulometric distribution of bottom ash

\begin{tabular}{lccccccccc} 
Particle size (mm) & 22 & 16 & 11.2 & 8 & 4 & 2 & 0.50 & 0.25 & 0.063 \\
\% Passing & 100 & 98 & 97 & 95 & 86 & 74 & 46 & 24 & 5 \\
\hline
\end{tabular}

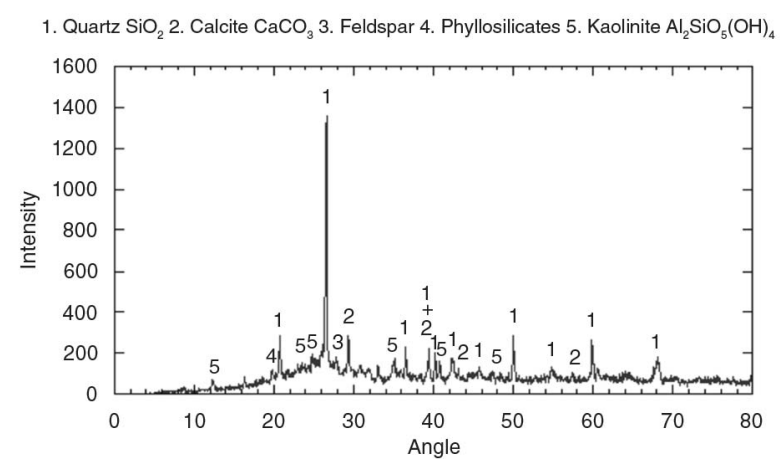

FIGURE 1. X-ray diffraction pattern of bottom ash.

prevailing phases are quartz and, to a lesser extent, calcite (calcium carbonate). Other minor phases such as feldspar and clay or phyllosilicates, kaolinite in particular, are also present.

The study of the chemical composition of the ash was carried out by scanning electron microscope (scanning electron microscope (SEM)). As Table 2 shows, this has a high percentage in silicates and aluminates and, to a lesser extent, iron and calcium oxides, the latter being the one which provides the pozzolanic characteristics. The rest of the ash components are due to unburned residues. According to the standard ASTM C 618, the bottom ash in this study can be classified as type Class $\mathrm{F}$, that is, those caused by calcinations of anthracite or bituminous coal.

In addition, tests were carried out to determine the bulk density and porosity according to the standard UNE-EN 1097-3, resulting in values of 0.86 and $1.114 \mathrm{gr} / \mathrm{cm}^{3}$ respectively. A specific density of $2.125 \mathrm{gr} / \mathrm{cm}^{3}$ was obtained according to the standard UNE-EN 1097-6, which was significantly lower than that of the conventional aggregates used in this study. The values corresponding to the collapse and free swelling test indexes were $0.017 \%$ and $-0.167 \%$ respectively, carried out according to the NLT- 254/99 and UNE-EN 103601 norms. The result of the sand equivalent test was $78 \%$ according to the standard UNE-EN 933-8.

TABLE 2. Chemical composition of bottom ash and lime

\begin{tabular}{lcc}
\hline Component & Bottom ash (\%) & Cal (\%) \\
\hline $\mathrm{SiO}_{2} \%$ & 43.6 & \\
$\mathrm{Al}_{2} \mathrm{O}_{3} \%$ & 23.5 & 6.00 \\
$\mathrm{Fe}_{2} \mathrm{O}_{3} \%$ & 6.77 & \\
$\mathrm{CaO} \%$ & 4.62 & 90.00 \\
$\mathrm{~K}_{2} \mathrm{O} \%$ & 2.72 & - \\
$\mathrm{MgO} \%$ & 1.32 & - \\
$\mathrm{TiO}_{2} \%$ & 0.93 & - \\
$\mathrm{C} \%$ & 15.3 & - \\
Other & $<1$ & - \\
\hline
\end{tabular}




\subsection{Hydrated lime}

The hydrated lime used in this study has a minimum content of $85 \% \mathrm{CaO}$ and, due to its use as filler in bituminous mixtures, it was sieved through a $0.063 \mathrm{~mm}$ sieve.

\subsection{Aggregates used}

In order to carry out the study, two types of aggregates with different behaviours were used. On the one hand, an ophitic aggregate was used as coarse aggregate for the asphalt mix. It has a flakiness index of 12 according to the UNE-EN 933-3 norm and a Los Angeles coefficient of 16 according to the UNE-EN 1097-2 norm. A crushed limestone aggregate from the Piedras Negras quarry was used as fine aggregate. It has a Los Angeles coefficient of 22, being free of organic matter, clay, etc. According to the UNE-EN 933-8 norm, the result of the sand equivalent test was 60 .

\subsection{Hydrocarbon binder}

The hydrocarbon binder used to manufacture and study all the bituminous mixes was a type $\mathrm{B}$ 50/70 binder.

\section{METHODOLOGY}

This study focuses on the analysis of three bituminous mixes with widespread use in the design and construction of roads. The chosen mixes are two semi-dense mixes, denominated $16 \mathrm{~S}$ Surf and AC-22 S Bin according to the European standards, and another porous mix, PA-11. The AC-16 S Surf and PA-11 mixes are used in road surfaces and AC-22 S Bin in road binder layers (binder layers).

The manufacturing and testing of the test-pieces were carried out according to the Spanish standard PG-3. In order to use the ash as filler in this study, it was necessary to grind it with a Micro-Deval mill. Due to the fact that the ophitic aggregate is acidic, it has low aggregate-binder adhesiveness and so a basic limestone aggregate was used for the fine aggregate fraction. This aggregate was used in sizes between 0.50 and $0.063 \mathrm{~mm}$. in the AC-16 and $\mathrm{AC}-22$ mixes and between 2 and $0.063 \mathrm{~mm}$. in the PA-11 mix.
Initially, reference mixes with mineral filler (control mixes) were used in order to be able to compare their results with those obtained with the studied modified mixes (test mixes). The limestone filler of the latter was progressively substituted by an ash and lime combination in order to obtain their optimum values as filler in the mixture. The ash and lime combinations studied as fillers are the following: i) 100\% lime, ii) $50 \%$ ash and 50\% lime, iii) $70 \%$ ash and 30\% lime and iv) $100 \%$ ash. The optimum content of ash and lime was obtained from the tests carried out on these mixtures.

\subsection{Granulometry}

The granulometries used in this study correspond to the granulometric standards proposed by PG3, articles 542 and 543 of the Spanish regulation, based on the standard EN 12697-2. In order to study the effect of the ash and lime on the mixtures under study, the granulometries of the reference mix (control mixes) and modified mix (test mixtures) are identical. The granulometries used in this study are shown in Table 3.

\subsection{Bituminous mix design}

In order to design the bituminous mixes, the void content of the mix (EN-12697-8) is studied in test-pieces made according to EN 12697-30, both included in PG-3 of the Spanish norm. The semi-dense mixes studied (AC-16 and AC-22) were designed using a compaction of 75 blows on each side and with an average void content established in the standard $(5 \%)$. The porous mixture PA-11 was designed according to the EN 12697-30 norm and was compacted using 50 blows on each side. Furthermore, in order to limit the loss of the mix cohesion due to its high void content (20\%), the EN 12697-17 norm must be fulfilled in relation to the Cantabrian test of loss due to wear. In this test, the Marshall test-piece undergoes a tumbling process for 300 cycles in a Los Angeles machine, obtaining the particle loss from the weight difference.

\subsection{Water sensitivity}

Sensitivity to water is tested by the indirect traction strength ratio (ITSR) after immersion at $40{ }^{\circ} \mathrm{C}$. In this way, the effect of water on the bituminous

TABLE 3. Granulometric distribution of bituminous mixtures

\begin{tabular}{lcccccccccc}
\hline Bituminous mix & $\mathbf{3 2}$ & $\mathbf{2 2}$ & $\mathbf{1 6}$ & $\mathbf{1 1 . 2}$ & $\mathbf{8}$ & $\mathbf{4}$ & $\mathbf{2}$ & $\mathbf{0 . 5 0}$ & $\mathbf{0 . 2 5}$ & $\mathbf{0 . 0 6 3}$ \\
\hline AC-16 S Surf & - & 100 & 95 & 76 & 67 & 42 & 31 & 16 & 11 & 5 \\
AC-22 S Bin & 100 & 95 & 79 & 66 & 58 & 44 & 31 & 16 & 11 & 5 \\
PA -11 & - & - & 100 & 95 & 58 & 17 & 12 & 7 & 6 & 5 \\
\hline
\end{tabular}


mixes can be analysed and the aggregate-binder affinity can be studied. The Spanish norms limit the resulting values to a minimum value of $85 \%$ for road surfaces and $80 \%$, for the other layers. The test is in accordance with the UNE-EN 12697-12 norm.

\subsection{Stiffness modulus}

The stiffness moduli of the different mixes are obtained at $10{ }^{\circ} \mathrm{C}$ and $20^{\circ} \mathrm{C}$, according to appendix $\mathrm{C}$ of the UNE-EN 12697-26 norm. The test-pieces were made according to the Marshall methodology included in the UNE-EN 12697-30 norm.

\subsection{Fatigue test}

The fatigue tests on bituminous mixtures are carried out through load control according to appendix E of the UNE-EN 12697-24 norm, for cylindrical test-pieces. This test-pieces were made with the gyratory compactor, in accordance with the norm, taking into account the following fabrication criteria: i) the optimum binder content is the one determined by the Marshall test and ii) the density of the test-pieces was at least $97 \%$ of that obtained in the Marshall test, The gyratory compactor obtained a geometric density and the Marshall density is a saturated surface dry density. The gyratory compactor reaches this density when 200 cycles are applied, approximately.

The breakage criterion for this test was that the modulus of the material reached half of the initial modulus.

Regarding the number of test-pieces necessary to obtain the fatigue law, the norm establishes the use of three applied loads and three test-pieces for each of these loads, so that the minimum number of testpieces is 9. Furthermore, the load applied on the test-pieces must create an initial deformation, ranging between 100 and $400 \mu \varepsilon$ in the $10^{\text {th }}$ load cycle. Regarding the test repetition frequency, this is limited to $2 \mathrm{~Hz}$, due to the fact that bituminous mixes are plastic-elastic-viscous materials with a phase angle between stress and deformation.

\subsection{Wheel-tracking test}

The tracking test included in the UNE-EN 12697-22 norm consists in subjecting a test-piece to a series of load cycles by rolling a wheel which applies a certain load $(700 \mathrm{~N})$ at a specified temperature $\left(60^{\circ} \mathrm{C}\right)$ throughout the whole test.

The procedure followed is in accordance with "B" in air. The test-pieces were made by the segment compactor according to the UNE-EN 12697 33 norm, the size being $410 \times 260 \mathrm{~mm}$, with variable thickness according to maximum size of the aggregate used. For the AC-16 and AC-22 test-pieces the thickness was $60 \mathrm{~mm}$. and for the PA-11 mix, it was $40 \mathrm{~mm}$. The content of binder is the optimum obtained in the Marshall test and the density reached by the plate compactor corresponds to $100 \%$ of the one obtained in the Marshall test. For each type of asphalt mix studied, two test-pieces were made according to the norm for the test.

\section{RESULTS AND DISCUSSION}

\subsection{Bituminous mix design}

The results obtained for the design of mixes with PCC-BA as filler from the starting point of void content of the mixture according to the Marshall method are shown in Table 4. As can be seen, the use of PCC-BA and/or HL as filler in the mixes implies a significant increase in the optimum binder content in relation to control mixtures. Some authors have demonstrated a similar effect for HMA mixtures with MSWI-BA filler (5-8). This is due to the high specific surface of both and the high porosity of the ashes. This increase is lower for the porous mixture PA-11 due to the lower filler content it requires to reach its minimum void content $(20 \%)$ according to the standard. It has been demonstrated (Estakhri, C.K., and Saylak, D., 2000) that through a treatment of the ashes with sulphur this increase in the optimum binder content can be neutralised.

The densities obtained for these optimum binder contents are shown in Table 5. As can be seen, the densities of the trial mixes have a lower density than the control mixes (8-10). This is due to the lower specific density of lime and ash with respect to natural aggregates. The highest densities are reached for a combination of around $70 \%$ bottom ash and $30 \%$ hydrated lime, although in the case of the mixture PA-11 it is slightly lower. These higher density

TABLE 4. Marshall optimum void (\%)

\begin{tabular}{|c|c|c|c|c|c|c|}
\hline \multirow{2}{*}{$\begin{array}{l}\text { Bituminous } \\
\text { mixture }\end{array}$} & \multirow{2}{*}{$\begin{array}{c}\text { Voids } \\
\text { mixture } \\
(\%)\end{array}$} & \multirow{2}{*}{$\begin{array}{l}\text { Filler } \\
\text { mineral }\end{array}$} & \multicolumn{4}{|c|}{$\begin{array}{l}\text { Bottom ash (\%) I } \\
\text { Hydrated lime (\%) }\end{array}$} \\
\hline & & & $0 / 100$ & $50 / 50$ & $70 / 30$ & $100 / 0$ \\
\hline AC-16 S Surf & 5 & 4.58 & 5.70 & 5.36 & 5.23 & 4.76 \\
\hline AC-22 S Bin & 5 & 4.20 & 5.33 & 5.00 & 4.87 & 4.45 \\
\hline PA-11 & 20 & 4.15 & 4.50 & 4.37 & 4.50 & 4.50 \\
\hline
\end{tabular}

TAble 5. Marshall density $\left(\mathrm{KN} / \mathrm{m}^{3}\right)$

\begin{tabular}{|c|c|c|c|c|c|c|}
\hline \multirow{2}{*}{$\begin{array}{l}\text { Bituminous } \\
\text { mixture }\end{array}$} & \multirow{2}{*}{$\begin{array}{c}\text { Voids } \\
\text { mixture } \\
(\%)\end{array}$} & \multirow{2}{*}{$\begin{array}{l}\text { Filler } \\
\text { mineral }\end{array}$} & \multicolumn{4}{|c|}{$\begin{array}{c}\text { Bottom ash (\%) I } \\
\text { Hydrated lime (\%) }\end{array}$} \\
\hline & & & $0 / 100$ & $50 / 50$ & $70 / 30$ & $100 / 0$ \\
\hline AC-16 S Surf & 5 & 25.51 & 24.95 & 25.09 & 25.15 & 25.10 \\
\hline AC-22 S Bin & 5 & 25.65 & 25.01 & 25.20 & 25.28 & 25.18 \\
\hline PA-11 & 20 & 21.56 & 21.30 & 21.52 & 21.43 & 21.40 \\
\hline
\end{tabular}


values of the mix imply better performance of the mix and an increase in the useful lifespan.

\subsection{Water sensitivity}

Throughout this test, carried out on semi-dense mixes, it was observed that the filler made up exclusively of bottom ash did not achieve the minimum value required by the PG-3 norm, corresponding to $85 \%$ of the ITSR (indirect tensile strength ratio), which was indeed achieved by the reference mixtures. Therefore, lime and ash combined was chosen for use as filler. As can be seen in Table 6, the result of this combination results in a significant increase in the values of the conserved resistance due to the excellent affinity that lime shows with the bituminous binder $(11,12)$. This increase in the ITSR was of the order of $15 \%$ in the analysed mixes (13). However, the addition of lime to the mix implies a significant increase in the optimum binder content and a decrease in the density of the resulting mixture. Consequently, the lime content was limited in the tests carried out afterwards, focusing the study on mixtures with a content of $70 \%$ ash and $30 \%$ lime. This content get the values required by the Spanish normative (PG-3) for all mixtures.

\subsection{Stiffness modulus}

The dynamic moduli corresponding to bituminous mixes with a filler combination of $70 \%$ bottom ash and 30\% hydrated lime are shown in Table 7. At the same temperature, the values of the stiffness modulus of the mixes with a filler of ash and lime

TABLE 6. Indirect Tensile Strength Ratio (ITSR \%)

\begin{tabular}{lccccccc}
\hline & \multirow{2}{*}{$\begin{array}{c}\text { Voids } \\
\text { mituminous } \\
\text { mixture } \\
\text { mixture }\end{array}$} & $\begin{array}{c}\text { Filler } \\
\text { mineral }\end{array}$ & \multicolumn{4}{c}{$\begin{array}{c}\text { Bottom ash (\%) I } \\
\text { Hydrated lime (\%) }\end{array}$} \\
\cline { 5 - 8 } AC-16 S Surf & 5 & 85 & 87 & 91 & 89 & 77 \\
AC-22 S Bin & 5 & 90 & 88 & 87 & 86 & 75 \\
PA-11 & 20 & 88 & 82 & 84 & 87 & 74 \\
\hline
\end{tabular}

TABLE 7. Stiffness modulus

\begin{tabular}{lccccc}
\hline \multirow{2}{*}{$\begin{array}{l}\text { Bituminous } \\
\text { mixture }\end{array}$} & Filler & $\begin{array}{c}\text { Optimum } \\
\text { binder content } \\
(\% \text { on mixture) }\end{array}$ & \multicolumn{2}{c}{$\begin{array}{c}\text { Stiffness } \\
\text { modulus (MPa) }\end{array}$} \\
\hline AC-16 S Surf & Mineral & 4.58 & 14825 & 5687 \\
& $70 \%$ BA+30 $\%$ HL & 5.23 & 14893 & 6632 \\
AC-22 S Bin & Mineral & 4.20 & 13774 & 5830 \\
& $70 \%$ BA+30 $\%$ HL & 4.87 & 14019 & 5946 \\
PA-11 & Mineral & 4.15 & 7670 & 1854 \\
& $70 \%$ BA+30 $\% \mathrm{HL}$ & 4.50 & 8300 & 2268 \\
\hline
\end{tabular}

are slightly higher $(11,14)$. As temperature decreases its stiffness modulus increases significantly.

The results obtained for the PA-11 porous mixtures have far lower moduli than those of semi-dense mixes, making them more deformable. This is mainly due to the high void content of these mixtures. Taking into account these results, their study for fatigue and plastic deformation was discarded.

\subsection{Fatigue test}

The fatigue tests carried out on the mixes focused on in the study along with the control mixes led to the laws shown in Figure 2. The AC-16 S mixes resulted in the following fatigue laws shown on a doubly logarithmic scale. The correlation coefficients obtained are high.

As can be seen from the results of the AC-16 S mix, both straight lines turn out to be very similar; which is because their slopes are very similar. That is why both mixtures have similar fatigue breakage sensitivity depending on the applied load. The empirically obtained fatigue laws are as follows [1], [2]:

$$
\begin{aligned}
& \text { Reference mixtures (mineral filler): } \\
& \qquad N_{F}=3 \times 10^{11}\left(1 / \varepsilon_{0}\right)^{3.78} \\
& \text { Test mixtures }(70 \% \mathrm{BA} \text { and } 30 \% \mathrm{HL}) \text { : } \\
& N_{F}=8 \times 10^{11}\left(1 / \varepsilon_{0}\right)^{4}
\end{aligned}
$$

The results obtained for the AC-22 S mixtures show that the trial mixtures, made up of $70 \%$ ash and 30\% lime filler, have a higher sensitivity to the variation of the applied load throughout the lifespan under fatigue than the reference mixture. For both mixtures, reasonably good statistical correlation values were obtained, which demonstrates that the laws obtained are representative of the performance of the material studied. The empirically obtained fatigue laws are as follows [3], [4]:

$$
\begin{aligned}
& \text { Reference mixtures (mineral filler): } \\
& N_{F}=10^{13} \times\left(1 / \varepsilon_{0}\right)^{4.59}
\end{aligned}
$$

$$
\begin{aligned}
& \text { Test mixtures }(70 \% \mathrm{BA} \text { and } 30 \% \mathrm{HL}) \text { : } \\
& N_{F}=10^{19} \times\left(1 / \varepsilon_{0}\right)^{8.18}
\end{aligned}
$$

\subsection{Wheel-tracking test}

As can be seen in the graph related to the control test-samples of the mixture AC-16 S Surf (Figure 3) the maximum values of vertical displacement reached in the two test-pieces are small, on average around $1.90 \mathrm{~mm}$, and as a direct consequence of the high strength under plastic deformations of this type of mix. The value obtained of average slope is 0.07 .

For the AC-16 S Surf mix with a combination of bottom ash and lime as filler, it can be seen that the 

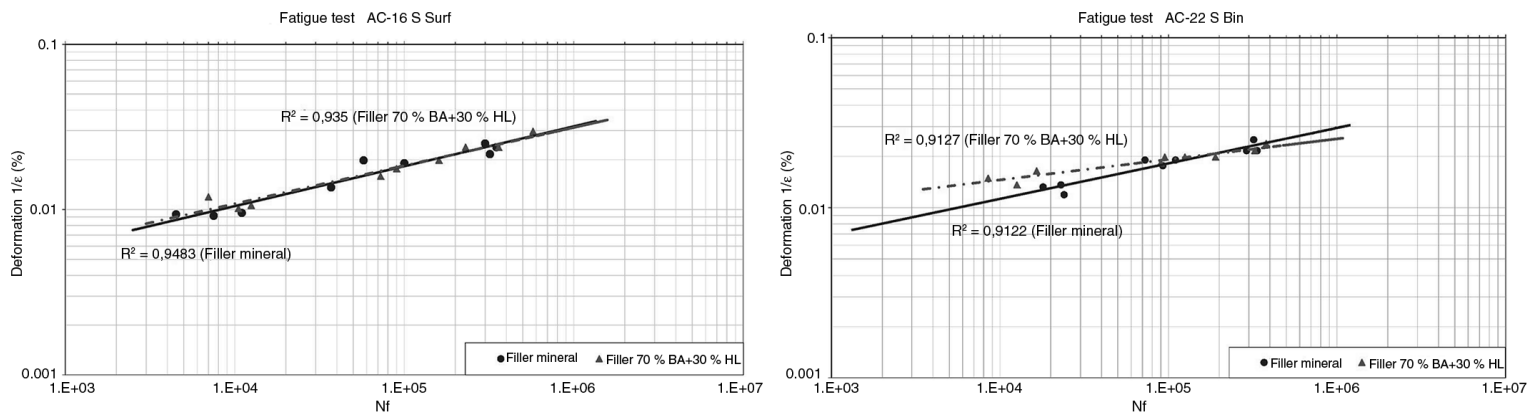

Figure 2. Fatigue test results.
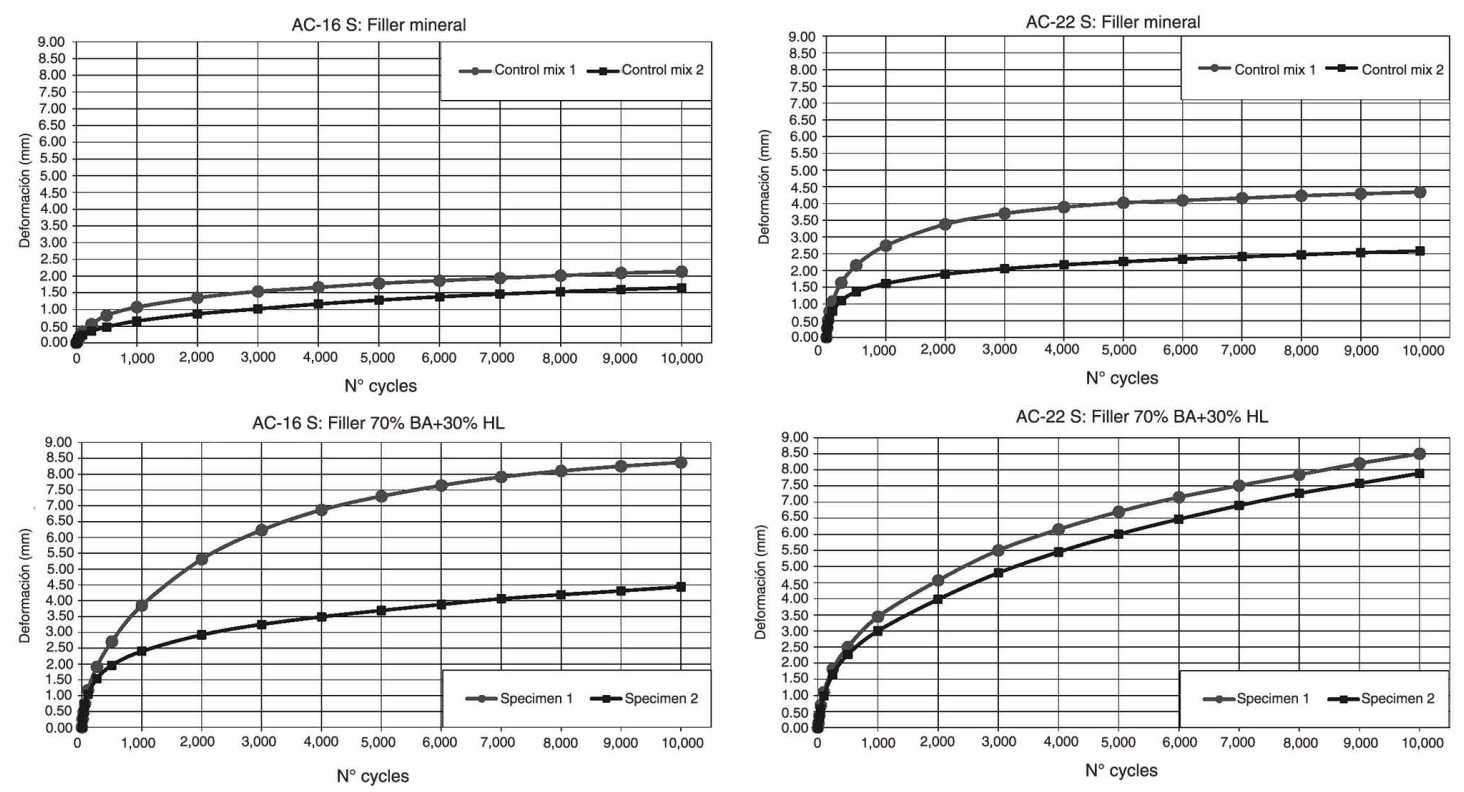

FIGURE 3. Wheel-tracking test results.

deformation values become stable between 3000 and 5000 cycles for both test-pieces, given that the slope of the curves diminishes until it becomes stable at 5000 cycles. However, its displacement velocity is still high for the range from 5000 to 10000 cycles, for which an average deformation slope value in the wheel-tracking test of $0.18 \mathrm{~mm}$ is obtained for every 1000 loading cycles. The values of the average slopes obtained for the AC-16 mixes with an ash and lime combination filler are higher than those obtained for conventional part limestone filler mixes. This is mainly due to the increase in the bituminous binder content and the decrease in the filler/bitumen ratio. This is critical since the strength decreases due to the internal friction among particles and due to its rheological behaviour, given that it is a low-viscosity material at high temperatures.

The curves obtained with the reference AC-22 S Bin mixes (control mixes) have a quite constant displacement velocity in the range of values studied in the test, from 5000 to 10000 cycles. This is because, once the process of readjustment of the particles is complete, the mix is stiffer thanks to the higher content of large particles (sizes 16/22 and 22/32) and, therefore, is less susceptible to undergo settling under plastic deformation. As a result, the value of the average displacement slope obtained on the track was 0.06. However, the AC-22 S Bin mixes with ash and lime filler both behave in a similar way, providing an average displacement slope of 0.37 . It was also observed that, due to the larger content in bitumen in the mixes whose filler is a combination of ash and lime compared to the reference mixes, the final displacements are also larger.

In the same way, given that the increase in the optimum content of binder in all the mixes with ash and lime filler compared to the reference mixes is greater in the AC-22 type than in the AC-16 type, the final deformations obtained were also greater. 
This corroborates the results obtained by other authors $(5,7,9)$.

\section{CONCLUSIONS}

It is necessary to add lime to the ash filler, given that the substitution of the original filler by ash produced a mix with insufficient adherence between the aggregate and the binder as the minimum values required by the norms in the water sensitivity test were not achieved. The addition of lime produced a significant improvement in the adherence of the mix so avoiding problems of stripping.

The addition of lime in the ash filler gave rise to an increase in the optimum content of binder.

Among all the combinations of filler studied, the one with $70 \%$ ash and $30 \%$ lime by total weight of aggregate is outstanding, given that it provides better behaviour in the dosing of the HMA mixes. At the same time, these mixes fulfil the specifications in the water sensitivity test satisfactorily.

The wheel-tracking tests carried out to quantify the plastic deformations (rutting) demonstrate that the reference mixes AC-16-S and AC-22-S, with limestone filler, have an average slope of 0.07 and $0.06 \mathrm{~mm}$ for every 1000 cycles respectively, so they can be used for the road surface layer for any type of climate and traffic. However, the mixes with a $70 \%$ ash and 30\% lime filler have a slope of up to 0.18 and $0.37 \mathrm{~mm}$. For every 1000 cycles respectively, so their use is limited to light traffic. This large difference is due to the increase in the optimum binder content caused by the decrease in the filler/bitumen ratio and the decrease in internal friction among the particles that create more deformable and flexible HMA mixes.

In the fatigue test, the reference AC-16 mixes and the filler combination of hydrated lime and bottom ash display very similar behaviour. Nevertheless, the AC-22 mix with ash and lime filler behaves in a more sensitive way toward the variation of applied load.

The use of bituminous mixes AC-16 S Surf, AC-22 S Bin and PA-11 with a filler combination of $70 \%$ bottom ash and $30 \%$ of hydrated lime is recommended for road surfaces and intermediate layers with light traffic and small infrastructures. This content get the values required by the Spanish Normative (PG-3).

\section{REFERENCES}

1. International Energy Agency (IEA) (2009) Key world energy statistics.

2. American Coal Ash Association (ACAA) (2010) 2008 Coal combustion product (CCP) production and use survey report.

3. Vega-Zamanillo, A.; Calzada-Pérez, M.A.; Pascual-Montejo, I.; Hernández-Sanz, A. (2008) Compactación y capacidad portante de cenizas de central térmica en terraplenes de carreteras. Revista Carreteras de la Asociación Española de la Carretera 161, 45-53.

4. Forteza, R.; Far, M.; Seguí, C.; Cerdá, V. (2004) Characterization of bottom ash in municipal solid waste incinerators for its use in road base. Waste management 24 [9], 899-909. http://dx.doi.org/10.1016/j.wasman.2004.07.004.

5. Ogunro, V.O.; Inyang, H.I.; Hooper, F.; Young, D.; Oturkar, A. (2004) Gradation control of bottom ash aggregate in superpave bituminous mixes. Journal of Materials in Civil Engineering 16 [6], 604-613. http://dx.doi.org/10.1061/ (ASCE)0899-1561(2004)16:6(604).

6. Huang, C.M.; Chiu, C.T.; Li, K.C.; Yang, W.F. (2006) Physical and environmental properties of asphalt mixtures containing incinerator bottom ash. Journal of Hazardous Materials 137 [3], 1742-1749. http://dx.doi.org/10.1016/j. jhazmat.2006.05.016.

7. Goh, S.W.; You, Z. (2008) A preliminary study of the mechanical properties of asphalt mixture containing bottom ash. Canadian Journal of Civil Engineering 35 [10], 1114-1119. http://dx.doi.org/10.1139/L08-071.

8. Chen, Jian-Shiuh; Chu, Po-Yen; Chang, Juu-En; Lu, HsingCheng; Wu, Zen-How; Lin, Kuei-Yi. (2008) Engineering and environmental characterization of municipal solid waste bottom ash as aggregate substitute utilized for asphalt concrete. Journal of Materials in Civil Engineering 20 [6], 432-439. http://dx.doi.org/10.1061/(ASCE)0899-1561(2008) 20:6(432).

9. Kandhal, P.S. (1992) Waste materials in hot mix asphalt an overview. NCAT Report No. 92-6, 1-11.

10. Vassiliadou Churchill, E.; Amirkhanian, S.N. (1999) Coal ash utilization in asphalt concrete mixtures. Journal of Materials in Civil Engineering 11 [4], 295-301. http://dx.doi. org/10.1061/(ASCE)0899-1561(1999)11:4(295).

11. Mohammad, L.N.; Abadie, C.; Gokmen, R.; Puppala, A.J. (2000) Mechanistic evaluation of hydrated lime in hot mix asphalt mixtures. Journal of the Transportation Research Board 1723/2000, 26-36. http://dx.doi.org/10.1007/97894-007-4566-7_89.

12. Sebaaly, P.E.; Little, D.N.; Epps, J.A. (2006) The benefits of hydrated lime in hot mix asphalt. National Lime Association.

13. Zeng, M.; Ksaibati, K. (2003) Evaluation of moisture susceptibility of asphalt mixtures containing bottom ash. Journal of the Transportation Research Board 1832/2003, 25-33. http://dx.doi.org/10.3141/1832-04.

14. Sacramento Aragão, F.T.; Lee, J.; Kim, Y.R.; Karki, P. (2009) Material specific effects of hydrated lime on the properties and performance behavior of asphalt mixtures and asphaltic pavements. Constr. Build. Mater. 24 [4], 538-544. http:// dx.doi.org/10.1016/j.conbuildmat.2009.10.005. 